Article

\title{
Dynamic of Phenolic Compounds, Antioxidant Activity, and Yield of Rhubarb under Chemical, Organic and Biological Fertilization
}

\author{
Alexandru Cojocaru ${ }^{1}$, Laurian Vlase $\left.{ }^{2}{ }^{(}\right)$, Neculai Munteanu ${ }^{1}$, Teodor Stan ${ }^{1}$, \\ Gabriel Ciprian Teliban ${ }^{1}$, Marian Burducea ${ }^{1,3}$ and Vasile Stoleru ${ }^{1, *(D)}$ \\ 1 Department of Horticultural Technologies, “Ion Ionescu de la Brad" University of Agricultural Sciences and \\ Veterinary Medicine, 3 M. Sadoveanu, 700440 Iasi, Romania; cojocaru.alexandru@yahoo.com (A.C.); \\ nmunte@uaiasi.ro (N.M.); steodor@uaiasi.ro (T.S.); gabrielteliban@uaiasi.ro (G.C.T.); \\ marian.burducea@yahoo.com (M.B.) \\ 2 Department of Bio-pharmaceutics and Pharmaceutical Technology, Iuliu Hatieganu University of Medicine \\ and Pharmacy, 41 Victor Babes, 400012 Cluj Napoca, Romania; laurian.vlase@umfcluj.ro \\ 3 "Alexandru Ioan Cuza" University of Iasi, 11 Bd. Carol, 700506 Iasi, Romania \\ * Correspondence: vstoleru@uaiasi.ro
}

Received: 16 February 2020; Accepted: 7 March 2020; Published: 11 March 2020

\begin{abstract}
In recent years, rhubarb is being increasingly cultivated, as it provides early yields when the vegetables supply to market is deficient and shows high levels of both polyphenols content and antioxidant capacity in edible parts. In 2017, we investigated crops of the rhubarb cultivar Victoria to the fifth year of production. Comparisons were performed between three root phase fertilizations—chemical (NPK 16-16-16 ${ }^{\circledR}$ ), organic (Orgevit ${ }^{\circledR}$ ), and biological (Micoseeds MB ${ }^{\circledR}$ ) — plus an unfertilized control. The determinations of polyphenols, the antioxidant capacity, and the yield indicators from the stalks (petioles) of rhubarb were made at each out of the 10 harvests carried out. The highest yield ( $59.16 \mathrm{t} \cdot \mathrm{ha}^{-1}$ ) was recorded under the chemical fertilization. The total polyphenols content and antioxidant capacity varied widely from $533.86 \mathrm{mg} \mathrm{GAE} \cdot \mathrm{g}^{-1} \mathrm{~d} . \mathrm{w}$. and $136.86 \mathrm{mmol}$ Trolox $\cdot \mathrm{g}^{-1}$ d.w., respectively in the unfertilized control at the last harvest, up to $3966.56 \mathrm{mg} \mathrm{GAE} \cdot \mathrm{g}^{-1}$ d.w. and $1953.97 \mathrm{mmol}$ Trolox $\cdot \mathrm{g}^{-1} \mathrm{~d}$.w. respectively under the organic fertilization at the four harvest. From the results of our investigation, it can be inferred that the chemical fertilization was the most effective in terms of yield, whereas the sustainable nutritional management based on organic fertilizer supply led to higher antioxidant compounds and activity.
\end{abstract}

Keywords: Rheum rhabarbarum L.; fertilization; yield; polyphenols; $\mathrm{DPPH}^{+}$

\section{Introduction}

Rhubarb (Rheum rhabarbarum L.) is a perennial plant [1] that is characterized by high antioxidant properties and is cultivated only for its petiole [2], as its leaves are toxic due to their content of oxalic acid [3]. In Europe, it is cultivated mainly in Germany, France, and England [4]. Stalks are used for the preparation of various culinary preparations (soup, pie, compote, sweetness), but they are also used in traditional medicine as laxatives, gastrointestinal hemorrhage, and the treatment of constipation jaundice and ulcer [5]. A study has shown promising anti-cancer properties and the broad therapeutic potential of anthraquinines in the petioles of rhubarb [6]. The consumption of rhubarb in large quantities has an adverse effect on the accumulation of calcium in the body [3].

The technology and the nutritional regime used to cultivate crops influence the petioles production and its composition [7]. Important benefits from crop production have been observed by applying radicular fertilizers especially when soil conditions are limiting root uptake [8]. This way, much lower 
quantities of fertilizers are required to sustain growth [9]. Due to the global population growth and the need to provide food, chemical fertilization remains the most used. Detailed studies have shown that chemically fertilized crops show yields varying widely from $26.39 \mathrm{t} \cdot \mathrm{ha}^{-1}$ to $39.08 \mathrm{t} \cdot \mathrm{ha}^{-1}$ [10]. Due to the growth of organic products in recent years, farmers have also shifted to less polluting fertilization means, such as organic ones, which provide economically satisfactory yields [11]. At the same time, the food safety of the fresh or processed product is a necessity [12].

Fertilizers and harvesting influence the rhubarb phenolic content and composition as well as the antioxidant activity [13-15]. Health beneficial, antioxidative, antimicrobial, and plant protective properties are influenced by the synergistic effect of polyphenolic compounds [16-18]. In previous studies on rhubarb, total polyphenol content and composition as well as antioxidant activity were significantly affected by harvest dates, fertilizations, and the combined effect of these two factors [7,19]. Literature reports indicate variations in antioxidant capacity from $491 \mu \mathrm{mol}$ Trolox $\cdot \mathrm{g}^{-1} \mathrm{~d} . \mathrm{w}$. , in case of the clone Victoria 574/27, up to $1242 \mu \mathrm{mol}$ Trolox $\cdot \mathrm{g}^{-1} \mathrm{~d} . \mathrm{w}$. , in the case of the Valentin variety [5].

It should be emphasized that literature data regarding the effect of fertilizers (chemical and biological) as well as of the harvesting times on the polyphenol content of the rhubarb stalks are missing. Kalisz et al. analyzed the polyphenol content of two cultivars (Victoria and Red Malinowy) in the spring and autumn seasons, recording the highest value of flavan-3-ols for Red Malinowy cultivar from spring harvest $\left(195.98 \mathrm{mg} \cdot \mathrm{g}^{-1} \mathrm{~d} . \mathrm{w}.\right)$ and the lowest for Victoria cv from autumn harvest $\left(86.57 \mathrm{mg} \cdot \mathrm{g}^{-1} \mathrm{~d}\right.$.w. [13]. Studies on other vegetable species belonging to the family Polygonaceae were performed on Rumex acetosa [19-22], Rumex scutatus [23], Rumex crispus [24,25], Rumex japonicus [26], Rumex hastatus [27-29], Rumex ecklonianus [30], Rumex tingitanus [31], Rumex sanguineus [32], Rumex acetosella [33], Rumex maderensis [34], and Rumex obtusifolius [35], but no determinations relevant to polyphenols content and composition were performed.

The main objectives of this research were to assess: (1) the influence of the chemical, organic, and biological fertilization on the dynamic yield and their quality (polyphenols, antioxidant capacity, etc.); and (2) the optimal harvesting periods, correspondent to the highest plant nutrient content, in order to promote fertilization measures for sustainable agriculture.

\section{Results and Discussion}

The total polyphenol content and antioxidant capacity were positively influenced by both the type of fertilization applied and the date of harvest compared to the unfertilized control. For the total polyphenol content, the highest statistically significant increase was recorded in the fertilized treatment with Mo (61.68\% compared to $\mathrm{Ct})$. The organic fertilization $(\mathrm{Og})$ provided $1477.95 \mathrm{mg} \mathrm{GAE} \cdot \mathrm{g}^{-1} \mathrm{~d} . \mathrm{w}$,

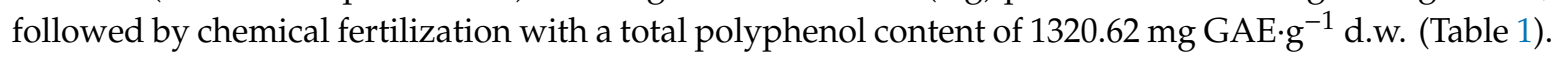
The role of arbuscular mychorrhizal fungi AMF should be taken into consideration in the Mo treatment as an abiotic stress according to environmental conditions [36].

The highest polyphenol content was recorded at the fourth harvesting period $\left(\mathrm{R}_{4}\right)$, with a value of $2450.86 \mathrm{mg} \mathrm{GAE} \cdot \mathrm{g}^{-1} \mathrm{~d} . \mathrm{w} .$, followed by fifth harvest $\left(\mathrm{R}_{5}\right)$ with a total polyphenol content of $1819.34 \mathrm{mg}$ $\mathrm{GAE} \mathrm{g}^{-1} \mathrm{~d}$.w. The lowest polyphenol content was recorded at the last harvest $\left(\mathrm{R}_{10}\right)$, i.e., $670.92 \mathrm{mg}$ $\mathrm{GAE} \mathrm{g}^{-1} \mathrm{~d}$.w. Statistically, lower values were recorded at the eighth harvest time $\left(\mathrm{R}_{8}\right)$ with a total polyphenol content of $1015.14 \mathrm{mg} \mathrm{GAE} \cdot \mathrm{g}^{-1} \mathrm{~d} . \mathrm{w}$.

The content of TP increased from $R_{1}$ to $R_{4}$ and $R_{5}$, after which it decreased toward the end of the production period, due to the reduction of the metabolism of the resent plants. Similar studies were also conducted in salad [37], where the total phenol content (TPC) was higher but dependent on the climatic conditions.

Regarding the influence of fertilization on antioxidant activity (AC), the highest values were recorded when fertilizing with $\mathrm{Mo}$, with the value of $877.07 \mathrm{mmol}$ Trolox $\cdot \mathrm{g}^{-1} \mathrm{~d} . \mathrm{w} .(280.06 \%$ against C), followed by the Og treatment, with the value of $728.05 \mathrm{mmol}$ Trolox $\cdot \mathrm{g}^{-1} \mathrm{~d} . \mathrm{w}$. $(232.47 \%$ compared to C). Ch fertilization resulted in an antioxidant activity of $478.48 \mathrm{mmol}$ Trolox $\cdot \mathrm{g}^{-1} \mathrm{~d} . \mathrm{w} .(152.52 \%$ compared to variant $\mathrm{C}$ ). 
Table 1. Main effects of the experimental factors on the total polyphenol content and antioxidant activity $(\mathrm{n}=3)$.

\begin{tabular}{|c|c|c|}
\hline Treatment & $\begin{array}{c}\text { Total Phenols Content-TPC } \\
\text { (mg GAE } \cdot \mathrm{g}^{-1} \text { d.w.) }\end{array}$ & $\begin{array}{l}\text { Antioxidant Activity-AC } \\
\left(\mathrm{mmol} \text { Trolox } \cdot \mathrm{g}^{-1} \text { d.w. }\right)\end{array}$ \\
\hline \multicolumn{3}{|l|}{ Fertilization } \\
\hline $\mathrm{Ch}$ & $1320.62 \pm 111.71^{b}$ & $478.48 \pm 41.43^{c}$ \\
\hline Mo & $1605.03 \pm 154.45^{\mathrm{a}}$ & $877.07 \pm 86.31^{a}$ \\
\hline $\mathrm{Og}$ & $1477.95 \pm 102.31^{\mathrm{ab}}$ & $728.05 \pm 50.68^{b}$ \\
\hline $\mathrm{C}$ & $992.74 \pm 87.35^{\mathrm{c}}$ & $313.17 \pm 26.78^{d}$ \\
\hline \multicolumn{3}{|l|}{ Harvest time } \\
\hline $\mathrm{R}_{1}$ & $1345.63 \pm 62.52^{c}$ & $582.73 \pm 51.14$ \\
\hline $\mathrm{R}_{2}$ & $1364.14 \pm 47.86^{\mathrm{c}}$ & $589.75 \pm 48.89^{c}$ \\
\hline $\mathrm{R}_{3}$ & $1315.55 \pm 80.32^{\mathrm{cd}}$ & $565.12 \pm 48.75^{c}$ \\
\hline $\mathrm{R}_{4}$ & $2450.83 \pm 287.23^{a}$ & $1079.76 \pm 165.65^{a}$ \\
\hline $\mathrm{R}_{5}$ & $1819.34 \pm 213.24^{b}$ & $834.44 \pm 147.00^{b}$ \\
\hline $\mathrm{R}_{6}$ & $1259.78 \pm 240.31^{\mathrm{cd}}$ & $586.83 \pm 147.35^{c}$ \\
\hline $\mathrm{R}_{7}$ & $1164.37 \pm 144.00^{\mathrm{cd}}$ & $515.47 \pm 69.14^{c}$ \\
\hline $\mathrm{R}_{8}$ & $1015.14 \pm 109.14^{\mathrm{d}}$ & $467.39 \pm 73.83^{c}$ \\
\hline $\mathrm{R}_{9}$ & $1085.13 \pm 77.13^{\mathrm{cd}}$ & $477.34 \pm 52.5^{\mathrm{c}}$ \\
\hline $\mathrm{R}_{10}$ & $670.92 \pm 50.3^{\mathrm{e}}$ & $293.09 \pm 31.19^{d}$ \\
\hline
\end{tabular}

$\mathrm{Ch}-$ Chemical; Mo-Biological; Og-Organic; $\mathrm{C}-\mathrm{Control}$; $\mathrm{R}_{1}-\mathrm{R}_{10}$ (first harvest time- the 10th harvesting time); GAE-Gallic Acid Equivalents. Within each column; Mean \pm standard deviation of each variable is reported in correspondence with each experimental treatment. Along each line, values followed by different letters are significantly different according to Tukey's test at $p \leq 0.05$.

Regarding the influence of the harvesting season on the antioxidant activity, the values ranged in the wide interval from $293.09 \mathrm{mmol}$ Trolox.g ${ }^{-1} \mathrm{~d}$.w., in the case of $\mathrm{R}_{10}$, up to $1079.76 \mathrm{mmol}$ Trolox.g ${ }^{-1}$ d.w. in the case of the fourth harvesting season $\left(R_{4}\right)$. Higher statistically significant values of $A C$ compared to $C$ were recorded at $R_{5}\left(834.44 \mathrm{mmol}\right.$ Trolox $\cdot \mathrm{g}^{-1} \mathrm{~d} . \mathrm{w}$.) and at $\mathrm{R}_{2}\left(589.75 \mathrm{mmol}\right.$ Trolox $\cdot \mathrm{g}^{-1}$ d.w.). Statistically lower values of AC compared to $C$ were recorded at $R_{8}\left(467.39\right.$ mmol Trolox.g ${ }^{-1}$ d.w.) and $\mathrm{R}_{9}$ (477.34 mmol Trolox.g ${ }^{-1}$ d.w.).

From the data presented in Table 1, a positive correlation was observed between the values of the total polyphenols content and the antioxidant capacity. Higher levels of antioxidant activity were recorded in the middle of the harvest period $\left(R_{4}\right.$ and $\left.R_{5}\right)$.

Data obtained from this study are in agreement with those reported for other Polygonaceae familly species such as English spinach [38] and sorrel [39].

Regarding the influence of fertilization and harvesting time on the total polyphenols content, statistically significant differences were recorded (Table 2).

Indeed, the total polyphenols broadly varied from $433.86 \mathrm{mg} \mathrm{GAE} \cdot \mathrm{g}^{-1} \mathrm{~d} . w .$, in the case of $\mathrm{R}_{10}$, unfertilized, up to $3966.56 \mathrm{mg} \mathrm{GAE} \cdot \mathrm{g}^{-1}$ d.w., in the case of $\mathrm{R}_{10}, \mathrm{Og}$ fertilization. (Table 2). In the case of $\mathrm{Ch}$, the total polyphenols content ranged from $829.51 \mathrm{mg} \mathrm{GAE} \cdot \mathrm{g}^{-1}$ d.w., at $\mathrm{R}_{8}$, to $1738.26 \mathrm{mg}$ GAE.g ${ }^{-1} \mathrm{~d}$.w., in the case of $\mathrm{R}_{4}$. When fertilizing with Mo, the total polyphenol content influenced by the harvesting time ranged in a wide interval from $660.88 \mathrm{mg}$ GAE.g ${ }^{-1} \mathrm{~d} . w$. ., in case $C$, up to $2954.52 \mathrm{mg}$ GAE.g ${ }^{-1}$ d.w., in case $R_{5}$. Upon Og fertilization, the polyphenol content ranged from $387.72 \mathrm{mg}$ GAE. ${ }^{-1}$ d.w., in the case of $R_{6}$, to $3966.56 \mathrm{mg} \mathrm{GAE} \cdot \mathrm{g}^{-1} \mathrm{~d}$.w., in the case of $\mathrm{R}_{4}$. The unfertilized control showed the lowest polyphenols content at $R_{10}\left(433.86 \mathrm{mg} \mathrm{GAE} \cdot \mathrm{g}^{-1} \mathrm{~d} . \mathrm{w}\right.$.), while at $\mathrm{R}_{4}$, the highest value

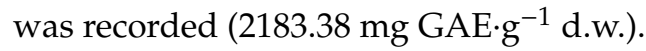

The data obtained in this experiment are in agreement with those obtained by Takeoka et al. who analyzed the content of polyphenols in the petioles of 29 different species of the genus Rheum harvested in two different years of production (2007 and 2009). The total polyphenols content ranged from $673 \mathrm{mg} \mathrm{GAE} \cdot \mathrm{g}^{-1}$ d.w., in the case of Loher Blut of the Rheum officinale species harvested in 2007, up to $4173 \mathrm{mg} \mathrm{GAE} \cdot \mathrm{g}^{-1}$ d.w., in the case of the Plum Hutt cv of the Rheum rhabarbarum L. species, harvested 
in 2009 [5]. Higher polyphenol content can be attributed to the effect of mycorrhizal associations, which induce a decrease in carbohydrate content in cells [40].

Regarding the influence of the fertilizer on the antioxidant capacity, this varied in wide limits from 136.86 mmol Trolox.g ${ }^{-1}$ d.w., in the case of $C$, from $R_{10}$, to 1953.97 mmol Trolox.g ${ }^{-1}$ d.w., in the case of $\mathrm{Og}$ fertilization, from $\mathrm{R}_{4}$ (Table 3 ).

Table 2. Interaction between harvest time and fertilization on TPC (mg GAE $\cdot g^{-1}$ d.w. $(n=3)$.

\begin{tabular}{|c|c|c|c|c|}
\hline \multirow{2}{*}{ Harvest Time } & \multicolumn{4}{|c|}{ Treatment } \\
\hline & $\mathrm{Ch}$ & Mo & $\mathrm{Og}$ & $\mathrm{C}$ \\
\hline $\mathrm{R}_{1}$ & $1431.34 \pm 119.09 \mathrm{ab}$ & $1427.73 \pm 125.68^{\mathrm{cd}}$ & $1332.73 \pm 104.3^{b c}$ & $1190.73 \pm 161.28^{b}$ \\
\hline $\mathrm{R}_{2}$ & $1449.88 \pm 81.00^{a b}$ & $1450.65 \pm 122.27 \mathrm{~cd}$ & $1324.53 \pm 90.65 b c$ & $1231.48 \pm 60.55^{b}$ \\
\hline $\mathrm{R}_{3}$ & $1610.11 \pm 186.78^{a}$ & $1329.76 \pm 161.31 \mathrm{~cd}$ & $1229.71 \pm 69.75 \mathrm{bcd}$ & $1092.62 \pm 64.38 \mathrm{bc}$ \\
\hline $\mathrm{R}_{4}$ & $1738.26 \pm 144.62^{a}$ & $1915.12 \pm 168.59 b c$ & $3966.56 \pm 310.41^{a}$ & $2183.38 \pm 295.73^{a}$ \\
\hline $\mathrm{R}_{5}$ & $1521.36 \pm 85.00^{a}$ & $2954.52 \pm 249.02^{a}$ & $1627.58 \pm 111.39^{b}$ & $1173.89 \pm 57.72^{b}$ \\
\hline $\mathrm{R}_{6}$ & $901.42 \pm 104.57^{b c}$ & $2569.88 \pm 311.75^{b}$ & $687.72 \pm 39.01^{\mathrm{d}}$ & $880.10 \pm 51.86^{b c d}$ \\
\hline $\mathrm{R}_{7}$ & $1704.53 \pm 141.82^{a}$ & $1285.07 \pm 113.13$ & $1218.81 \pm 95.38 \mathrm{bcd}$ & $449.08 \pm 60.82^{d}$ \\
\hline $\mathrm{R}_{8}$ & $829.51 \pm 46.34^{\mathrm{c}}$ & $1364.39 \pm 115.00^{\mathrm{cd}}$ & $1324.28 \pm 90.63 b c$ & $542.37 \pm 26.67^{\mathrm{cd}}$ \\
\hline $\mathrm{R}_{9}$ & $1188.14 \pm 137.83^{a b c}$ & $1092.31 \pm 132.51 \mathrm{~cd}$ & $1310.19 \pm 74.32 \mathrm{bcd}$ & $749.87 \pm 44.18^{b c d}$ \\
\hline $\mathrm{R}_{10}$ & $831.59 \pm 70.09^{c}$ & $660.88 \pm 45.23^{d}$ & $757.35 \pm 37.24^{\mathrm{cd}}$ & $433.86 \pm 50.33^{d}$ \\
\hline
\end{tabular}

Ch-Chemical; Mo-Biological; Og-Organic; C-Control; $\mathrm{R}_{1}-\mathrm{R}_{10}$ (first harvest time-the 10th harvesting time). Within each column; Mean \pm standard deviation of each variable is reported in correspondence with each experimental treatment. Along each line, values followed by different letters are significantly different according to Tukey's test at $p \leq 0.05$.

Table 3. Interaction between harvest time and fertilization on antioxidant capacity (mmol Trolox. $\mathrm{g}^{-1}$ d.w.) $(n=3)$.

\begin{tabular}{|c|c|c|c|c|}
\hline \multirow{2}{*}{ Harvest Time } & \multicolumn{4}{|c|}{ Treatment } \\
\hline & $\mathrm{Ch}$ & Mo & Og & $\mathrm{C}$ \\
\hline $\mathrm{R}_{1}$ & $518.60 \pm 43.15^{b c}$ & $780.18 \pm 68.68^{\mathrm{cd}}$ & $656.52 \pm 51.38 \mathrm{bc}$ & $375.62 \pm 50.88^{b}$ \\
\hline $\mathrm{R}_{2}$ & $525.32 \pm 29.35^{b}$ & $792.70 \pm 66.81^{\mathrm{cd}}$ & $652.48 \pm 44.66^{b c}$ & $388.48 \pm 19.10^{b}$ \\
\hline $\mathrm{R}_{3}$ & $583.37 \pm 67.67^{\mathrm{a}}$ & $726.64 \pm 88.15^{\mathrm{cd}}$ & $605.77 \pm 34.36^{\mathrm{bcd}}$ & $344.68 \pm 20.31^{b c}$ \\
\hline $\mathrm{R}_{4}$ & $629.80 \pm 52.40^{a}$ & $1046.51 \pm 92.13 \mathrm{bc}$ & $1953.97 \pm 152.91^{\mathrm{a}}$ & $688.76 \pm 93.29^{a}$ \\
\hline $\mathrm{R}_{5}$ & $551.22 \pm 30.80^{\mathrm{a}}$ & $1614.49 \pm 136.08^{a}$ & $801.76 \pm 54.87^{b}$ & $370.31 \pm 18.21^{b}$ \\
\hline $\mathrm{R}_{6}$ & $326.60 \pm 37.89 b c$ & $1404.31 \pm 170.36^{a b}$ & $338.78 \pm 19.22^{d}$ & $277.63 \pm 16.36^{b c d}$ \\
\hline $\mathrm{R}_{7}$ & $617.58 \pm 51.38^{a}$ & $702.22 \pm 61.82 \mathrm{~cd}$ & $600.40 \pm 46.99 \mathrm{bcd}$ & $141.67 \pm 19.19^{d}$ \\
\hline $\mathrm{R}_{8}$ & $300.55 \pm 16.79^{c}$ & $745.57 \pm 62.84^{\mathrm{cd}}$ & $652.35 \pm 44.65^{b c}$ & $171.09 \pm 8.41^{\mathrm{cd}}$ \\
\hline $\mathrm{R}_{9}$ & $430.49 \pm 49.94^{b c}$ & $596.89 \pm 72.41^{\mathrm{cd}}$ & $645.41 \pm 36.61 \mathrm{bcd}$ & $236.55 \pm 13.94^{b c d}$ \\
\hline $\mathrm{R}_{10}$ & $301.30 \pm 34.95^{c}$ & $361.14 \pm 43.81^{\mathrm{d}}$ & $373.08 \pm 21.16^{\mathrm{cd}}$ & $136.86 \pm 8.06^{\mathrm{d}}$ \\
\hline
\end{tabular}

Ch-Chemical; Mo-Biological; Og-Organic; C-Control; $\mathrm{R}_{1}-\mathrm{R}_{10}$ (first harvest time-the 10th harvesting time). Within each column, the mean \pm standard deviation of each variable is reported in correspondence with each experimental treatment. Along each line, values followed by different letters are significantly different according to Tukey's test at $p \leq 0.05$.

Regarding the influence of $\mathrm{Ch}$ on harvesting times, the antioxidant capacity ranged from 300.55 mmol Trolox.g ${ }^{-1}$ d.w., in the case of $R_{8}$, to 629.80 mmol Trolox.g ${ }^{-1}$ d.w., in the case of $R_{4}$. Under Mo fertilization, the lowest values of $A C$ were obtained at $R_{10}\left(361.14\right.$ mmol Trolox. ${ }^{-1}$ d.w.), while the highest values were recorded at $\mathrm{R}_{5}\left(1614.49 \mathrm{mmol}\right.$ Trolox. ${ }^{-1}$ d.w.). As far as $\mathrm{Og}$ is concerned, the antioxidant activity depended on harvesting time and varied widely from $338.78 \mathrm{mmol} \mathrm{Trolox} \cdot \mathrm{g}^{-1}$ d.w., in the case of $R_{6}$, to 1953.97 mmol Trolox.g ${ }^{-1}$ d.w., in case $R_{4}$. Then, the lowest values at the last harvest (136.86 mmol Trolox.g ${ }^{-1}$ d.w.) and the highest ones were obtained at $R_{4}(688.76 \mathrm{mmol}$ Trolox.g ${ }^{-1}$ d.w.).

Solfanelli et al. justify the higher content of polyphenolic compounds by the fact that in warmer periods, with less precipitation, the sugar content increases in plants and thus the activity of AMF is higher [41]. 
Studies on the influence of different fertilizers on the antioxidant capacity of the petioles of rhubarb are scant. Zhou et al. determined the antioxidant activity of commonly consumed vegetables in Colorado and found significant variation among individual samples of each vegetable tested. They ranked the antioxidant activity of the vegetables as follows: rhubarb > green bean; tomato > potato; kale $>$ spinach $>$ broccoli [4].

Takeoka et al. analyzed the antioxidant capacity of the 29 species of the genus Rheum. The antioxidant capacity ranged from $463 \mu \mathrm{mol}$ Trolox.g ${ }^{-1}$ d.w., in the case of Rheum officinale, up to $1242 \mu \mathrm{mol}$ Trolox.g ${ }^{-1}$ d.w., in the case of Valentine cv, of the species Rheum rhabarbarum L. [5].

In perennial species, as in Populus sp., high TPC and AC are also accounted for by water stress and higher temperatures [42].

In general, polyphenols are secondary metabolism compounds that are produced by plants for defensive purposes under increased biotic or abiotic stress.

The phenolic compounds content and composition were positively influenced by the application of fertilizers and the harvesting season, and in this respect, p-coumaric acid, ferulic acid, isoquercitrin, rutoside, and quercetrol were analyzed (Table 4).

Table 4. Main effects of the experimental factors on the polyphenol compounds $(n=3)$.

\begin{tabular}{|c|c|c|c|c|c|}
\hline Treatment & $\begin{array}{c}\text { P-Coumaric } \\
\text { Acid }\left(\mu g \cdot g^{-1}\right)\end{array}$ & $\begin{array}{l}\text { Ferulic Acid } \\
\quad\left(\mu g \cdot g^{-1}\right)\end{array}$ & $\begin{array}{l}\text { Isoquercitrin } \\
\left(\mu g \cdot g^{-1}\right)\end{array}$ & Rutozid $\left(\mu \mathrm{g} \cdot \mathrm{g}^{-1}\right)$ & $\begin{array}{l}\text { Quercetrol } \\
\left(\mu g \cdot g^{-1}\right)\end{array}$ \\
\hline \multicolumn{6}{|l|}{ Fertilization } \\
\hline $\mathrm{Ch}$ & $9.86 \pm 0.87^{c}$ & $21.67 \pm 1.76^{c}$ & $37.04 \pm 3.44^{c}$ & $473.2 \pm 37.97^{a}$ & $16.55 \pm 1.28^{b}$ \\
\hline Mo & $15.46 \pm 1.37^{\mathrm{a}}$ & $31.45 \pm 2.98^{a}$ & $78.65 \pm 5.58^{a}$ & $479.08 \pm 39.48^{a}$ & $20.20 \pm 1.87^{a}$ \\
\hline $\mathrm{Og}$ & $11.03 \pm 0.84^{b c}$ & $22.23 \pm 1.71^{\mathrm{c}}$ & $61.82 \pm 4.30^{b}$ & $490.97 \pm 42.42^{\mathrm{a}}$ & $15.94 \pm 1.41^{b}$ \\
\hline $\mathrm{C}$ & $11.58 \pm 0.98^{b}$ & $27.06 \pm 2.51^{b}$ & $68.2 \pm 6.22^{b}$ & $372.57 \pm 37.89^{b}$ & $11.17 \pm 0.96^{\mathrm{c}}$ \\
\hline \multicolumn{6}{|l|}{ Harvest time } \\
\hline $\mathrm{R}_{1}$ & $6.43 \pm 0.41^{\mathrm{e}}$ & $16.46 \pm 0.68^{d}$ & $47.26 \pm 6.48^{b}$ & $491.69 \pm 21.68^{\mathrm{cd}}$ & $11.22 \pm 0.78^{c}$ \\
\hline $\mathrm{R}_{2}$ & $6.72 \pm 0.36^{\mathrm{e}}$ & $16.76 \pm 0.81^{\mathrm{d}}$ & $48.66 \pm 6.39^{b}$ & $497.92 \pm 19.07^{\mathrm{c}}$ & $11.38 \pm 0.70^{c}$ \\
\hline $\mathrm{R}_{3}$ & $9.12 \pm 1.11$ cde & $25.55 \pm 3.89 \mathrm{bc}$ & $50.93 \pm 6.58^{b}$ & $462.48 \pm 31.60^{\mathrm{cd}}$ & $11.73 \pm 0.69 b c$ \\
\hline $\mathrm{R}_{4}$ & $18.45 \pm 2.52^{b}$ & $24.53 \pm 1.88^{c}$ & $75.58 \pm 9.41^{\mathrm{a}}$ & $904.12 \pm 110.43^{a}$ & $21.09 \pm 1.20^{a}$ \\
\hline $\mathrm{R}_{5}$ & $8.22 \pm 0.92 \mathrm{de}$ & $15.69 \pm 0.88^{\mathrm{d}}$ & $56.32 \pm 6.51^{b}$ & $666.61 \pm 65.75^{b}$ & $12.28 \pm 1.13^{b c}$ \\
\hline $\mathrm{R}_{6}$ & $10.32 \pm 1.32^{\mathrm{cd}}$ & $31.37 \pm 1.82^{b}$ & $84.83 \pm 16.41^{\mathrm{a}}$ & $382.32 \pm 76.61 \mathrm{de}$ & $15.31 \pm 1.76^{b}$ \\
\hline $\mathrm{R}_{7}$ & $23.57 \pm 4.04^{\mathrm{a}}$ & $38.44 \pm 3.56^{\mathrm{a}}$ & $58.63 \pm 8.76^{b}$ & $344.47 \pm 54.88^{\mathrm{e}}$ & $19.71 \pm 3.00^{\mathrm{a}}$ \\
\hline $\mathrm{R}_{8}$ & $7.61 \pm 0.95 \mathrm{de}$ & $39.96 \pm 3.20^{a}$ & $79.44 \pm 11.55^{\mathrm{a}}$ & $281.38 \pm 30.47$ ef & $13.94 \pm 1.61^{b c}$ \\
\hline $\mathrm{R}_{9}$ & $17.25 \pm 1.55^{b}$ & $26.30 \pm 1.53^{b c}$ & $80.21 \pm 7.03^{a}$ & $312.55 \pm 20.48^{e}$ & $21.64 \pm 1.51^{\mathrm{a}}$ \\
\hline $\mathrm{R}_{10}$ & $12.13 \pm 1.24^{\mathrm{c}}$ & $20.99 \pm 0.93^{c d}$ & $32.43 \pm 1.36^{\mathrm{c}}$ & $196.02 \pm 16.67^{f}$ & $21.37 \pm 2.63^{a}$ \\
\hline
\end{tabular}

Ch-Chemical; Mo-Biological; Og-Organic; $\mathrm{C}-\mathrm{Control}$; $\mathrm{R}_{1}-\mathrm{R}_{10}$ (first harvest time- the 10th harvesting time). Within each column, mean \pm standard deviation of each variable is reported in correspondence with each experimental treatment. Along each line, values followed by different letters are significantly different according to Tukey's test at $p \leq 0.05$.

The values of $\mathrm{p}$-coumaric ranged from $9.86 \mu \mathrm{g} \cdot \mathrm{g}^{-1}$, in the case of $\mathrm{Ch}$, to $15.46 \mu \mathrm{g} \cdot \mathrm{g}^{-1}$, in the case of the Mo fertilization. Control and Og treatment had higher values of $\mathrm{p}$-coumaric acid, of $17.44 \%$ and $11.86 \%$, respectively, compared to the Ch treatment.

Ferulic acid widely varied from $21.67 \mu \mathrm{g} \cdot \mathrm{g}^{-1}$, in the case of $\mathrm{Ch}$, to $31.45 \mu \mathrm{g} \cdot \mathrm{g}^{-1}$, in the case of the Mo treatment. Control and Og treatments showed increases of $24.87 \%$, respectively $2.58 \%$, compared to Ch.

Isoquercitrin was significantly influenced $(p \leq 0.05)$ by biological fertilization. Values ranged from $37.04 \mu \mathrm{g} \cdot \mathrm{g}^{-1}$, in the case of $\mathrm{Ch}$, to $78.65 \mu \mathrm{g} \cdot \mathrm{g}^{-1}$, in the case of Mo. Control and Og fertilization resulted in increases of $84.12 \%$, respectively $66.90 \%$, compared to the Ch treatment.

Out of the phenolic compounds, rutozide showed the highest content. Rutoside ranged in a wide interval from $372.57 \mu \mathrm{g} \cdot \mathrm{g}^{-1}$, in case $\mathrm{C}$, to $490.97 \mu \mathrm{g} \cdot \mathrm{g}^{-1}$, in the case of $\mathrm{Og}$. Under fertilization with $\mathrm{Ch}$ and Mo, $27.01 \%$ increases were obtained, respectively $25.58 \%$, compared to the unfertilized control. 
Quercetrol varied from $11.57 \mu \mathrm{g} \cdot \mathrm{g}^{-1}$ in the control to $20.20 \mu \mathrm{g} \cdot \mathrm{g}^{-1}$ in the case of the fertilization with Mo. In the case of $\mathrm{Og}$ and $\mathrm{Ch}$ fertilization, $48.16 \%$ and $42.70 \%$ increases were obtained, compared to $\mathrm{C}$.

The data from Table 4 regarding the influence of the treatment on the phenols quality highlight the favorable effect of the biofertilizers application on the crop, compared with Ch and C.

The harvesting time significantly influenced $(p \leq 0.05)$ phenol content as follows: the highest p-coumaric acid content was obtained at $R_{7}$, ferulic acid at $R_{8}$, isoquercitrin at $R_{6}$, rutozide at $R_{4}$, and quercetrol in $R_{9}$. The lowest content of p-coumaric acid was recorded at first harvest $\left(R_{1}\right)$, while the lowest content of ferulic acid was recorded at $R_{5}$, the lowest content of isoquercitrin and rutoside were recorded at the last harvest $\left(R_{10}\right)$, and the lowest content of quercetrol was recorded at $R_{9}$.

$\mathrm{P}$-coumaric acid varied within wide limits from $6.43 \mu \mathrm{g} \cdot \mathrm{g}^{-1}$ in the case of $R_{1}$ to $23.57 \mu \mathrm{g} \cdot \mathrm{g}^{-1}$ in the case of $\mathrm{R}_{7}$. Statistically higher values of the p-coumaric acid content in the petioles of rhubarb were obtained also at the $\mathrm{R}_{4}$ and $\mathrm{R}_{9}$ harvest times, with increases of $286.96 \%$ and $268.3 \%$ respectively compared to $R_{1}$, which indicates that this acid accumulates when the plants have overcome the early development stages, being also influenced by the climatic conditions [43].

Regarding the content of ferulic acid in the petioles of resin influenced by the harvesting season, it ranged from $15.69 \mu \mathrm{g} \cdot \mathrm{g}^{-1}$ in the case of $R_{10}$, to $39.96 \mu \mathrm{g} \cdot \mathrm{g}^{-1}$, in the case of $R_{8}$. Remarkable results were also obtained at the $R_{7}$ and $R_{6}$ times, with increases of $244.99 \%$ and $199.9 \%$ respectively compared to $R_{10}$. Ferulic acid showed statistically low values in the case of $R_{9}$ and $R_{8}$, with increases of $4.90 \%$ and $6.8 \%$ respectively compared to $\mathrm{R}_{10}$. These results indicate that ferulic acid also accumulates in the second half of the harvesting period.

The values of isoquercitrin from the petioles of resin influenced by the harvesting time varied widely from $32.43 \mu \mathrm{g} \cdot \mathrm{g}^{-1}$, in the case of $\mathrm{R}_{10}$, up to $84.83 \mu \mathrm{g} \cdot \mathrm{g}^{-1}$, in the case of $\mathrm{R}_{6}$, which suggests that isoquercitrin accumulates in the middle of the harvesting period. Increases of $247.33 \%$ and $244.96 \%$ were obtained at $R_{9}$ and $R_{8}$, compared to $R_{10}$. The low values of isoquercitrin were recorded at $R_{1}$ and $R_{2}$, with increases of $45.7 \%$ and $50 \%$ respectively compared to $R_{10}$.

The content of rutoside in the petioles of resale varied in wide limits of $196.02 \mu \mathrm{g} \cdot \mathrm{g}^{-1}$, in the case of $R_{10}$, up to $904.12 \mu \mathrm{g} \cdot \mathrm{g}^{-1}$, in the case of $R_{4}$. A higher content of rutoside was obtained by $R_{5}$ and $R_{2}$, with increases of $340.1 \%$ and $254 \%$ respectively compared to the 10 th harvest $\left(\mathrm{R}_{10}\right)$. Lower values of rutoside were achieved by $R_{8}$ and $R_{9}$, with increases of $43.54 \%$ and $59.4 \%$ respectively compared to $R_{10}$.

The content of quercetrol in the rhubarb petioles ranged from $11.22 \mu \mathrm{g} \cdot \mathrm{g}^{-1}$, in the case of $\mathrm{R}_{1}$, to $21.64 \mu \mathrm{g} \cdot \mathrm{g}^{-1}$, in the case of $R_{9}$. Higher values were obtained by $R_{10}$ and $R_{4}$, with increases of $90.5 \%$ and $88 \%$ respectively compared to $R_{1}$. Quercetrol achieved increases of $1.42 \%$ and $4.54 \%$ respectively in the $R_{2}$ and $R_{3}$ harvest periods.

Fertilization with Mo had a significant positive influence on p-coumaric acid, ferulic, isoquercitin, and quercetrol.

The positive influence of biological fertilizers on the content of polyphenols has also been demonstrated in species such as tomatoes [44,45] or peppers [46-48].

The type of fertilization and the harvesting season significantly influenced the content of the five polyphenols (p-coumaric acid, ferulic acid, isoquercitrin, rutoside, and quercetrol) (Table 5). 
Table 5. Interaction between fertilization type and harvest on the polyphenols composition $(\mathrm{n}=3)$.

\begin{tabular}{|c|c|c|c|c|c|}
\hline Treatment & $\begin{array}{c}\text { P-Coumaric } \\
\text { Acid }\left(\mu \mathrm{g} \cdot \mathrm{g}^{-1}\right)\end{array}$ & $\begin{array}{l}\text { Ferulic Acid } \\
\quad\left(\mu g \cdot g^{-1}\right)\end{array}$ & $\begin{array}{l}\text { Isoquercitrin } \\
\quad\left(\mu \mathrm{g} \cdot \mathrm{g}^{-1}\right)\end{array}$ & Rutozid $\left(\mu \mathrm{g} \cdot \mathrm{g}^{-1}\right)$ & $\begin{array}{c}\text { Quercetrol } \\
\left(\mu \mathrm{g} \cdot \mathrm{g}^{-1}\right)\end{array}$ \\
\hline \multicolumn{6}{|l|}{$\begin{array}{l}\text { Interaction } \\
\text { of factors }\end{array}$} \\
\hline $\mathrm{Ch} \times \mathrm{R}_{1}$ & $5.84 \pm 0.49^{\mathrm{ns}}$ & $14.02 \pm 0.78^{\mathrm{ns}}$ & $26.12 \pm 2.17^{b}$ & $547.04 \pm 42.81^{\mathrm{ns}}$ & $12.12 \pm 1.64^{\mathrm{ab}}$ \\
\hline $\mathrm{Mo} \times \mathrm{R}_{1}$ & $8.22 \pm 0.73^{\mathrm{ns}}$ & $18.50 \pm 1.56^{\mathrm{ns}}$ & $62.36 \pm 5.49^{a}$ & $454.58 \pm 61.57^{\mathrm{ns}}$ & $12.16 \pm 0.68^{a b}$ \\
\hline $\mathrm{Og} \times \mathrm{R}_{1}$ & $5.96 \pm 0.47^{\mathrm{ns}}$ & $16.44 \pm 1.12^{\mathrm{ns}}$ & $29.22 \pm 2.29^{b}$ & $478.24 \pm 26.72^{\mathrm{ns}}$ & $12.98 \pm 1.09^{a}$ \\
\hline $\mathrm{C} \times \mathrm{R}_{1}$ & $5.68 \pm 0.77^{n s}$ & $16.86 \pm 0.83^{\mathrm{ns}}$ & $71.34 \pm 9.66^{\mathrm{a}}$ & $486.90 \pm 41.04^{\mathrm{ns}}$ & $7.64 \pm 0.52^{b}$ \\
\hline $\mathrm{Ch} \times \mathrm{R}_{2}$ & $6.58 \pm 0.37^{a b}$ & $14.52 \pm 1.69 \mathrm{~ns}$ & $26.28 \pm 1.47^{b}$ & $553.40 \pm 37.88^{\mathrm{ns}}$ & $12.20 \pm 0.60^{a}$ \\
\hline $\mathrm{Mo} \times \mathrm{R}_{2}$ & $8.40 \pm 0.71^{\mathrm{a}}$ & $18.80 \pm 2.28^{n s}$ & $64.02 \pm 5.40^{\mathrm{a}}$ & $461.20 \pm 22.68^{\mathrm{ns}}$ & $12.32 \pm 1.02^{\mathrm{a}}$ \\
\hline $\mathrm{Og} \times \mathrm{R}_{2}$ & $6.06 \pm 0.42^{b}$ & $16.68 \pm 0.95^{\mathrm{ns}}$ & $30.54 \pm 2.09^{b}$ & $473.26 \pm 39.38^{\mathrm{ns}}$ & $12.96 \pm 1.14^{\mathrm{a}}$ \\
\hline $\mathrm{C} \times \mathrm{R}_{2}$ & $5.86 \pm 0.29^{b}$ & $17.02 \pm 1.00^{\mathrm{ns}}$ & $73.80 \pm 3.63^{a}$ & $503.84 \pm 44.35^{\mathrm{ns}}$ & $8.04 \pm 0.63 b$ \\
\hline $\mathrm{Ch} \times \mathrm{R}_{3}$ & $7.62 \pm 0.43^{b c}$ & $24.28 \pm 1.90^{b}$ & $28.58 \pm 3.32^{b}$ & $607.96 \pm 47.58^{a}$ & $12.28 \pm 1.66^{\mathrm{ns}}$ \\
\hline $\mathrm{Mo} \times \mathrm{R}_{3}$ & $14.84 \pm 0.87^{\mathrm{a}}$ & $45.52 \pm 6.17^{a}$ & $68.66 \pm 5.37^{\mathrm{a}}$ & $376.38 \pm 50.98^{b}$ & $12.28 \pm 0.69 \mathrm{~ns}$ \\
\hline $\mathrm{Og} \times \mathrm{R}_{3}$ & $8.82 \pm 0.78^{b}$ & $17.20 \pm 0.96^{b}$ & $31.66 \pm 4.29^{b}$ & $429.82 \pm 24.01^{\mathrm{ab}}$ & $13.38 \pm 1.13^{\mathrm{ns}}$ \\
\hline $\mathrm{C} \times \mathrm{R}_{3}$ & $5.20 \pm 0.41^{c}$ & $15.18 \pm 1.28^{b}$ & $74.82 \pm 4.18^{a}$ & $435.76 \pm 36.73^{a b}$ & $8.98 \pm 0.61^{\mathrm{ns}}$ \\
\hline $\mathrm{Ch} \times \mathrm{R}_{4}$ & $12.42 \pm 1.68 \mathrm{bc}$ & $19.22 \pm 1.32^{b}$ & $37.82 \pm 3.19^{c}$ & $646.56 \pm 44.25^{b}$ & $18.88 \pm 0.93^{\mathrm{ns}}$ \\
\hline $\mathrm{Mo} \times \mathrm{R}_{4}$ & $22.06 \pm 1.23^{a b}$ & $33.38 \pm 1.64^{\mathrm{a}}$ & $65.56 \pm 4.49^{b}$ & $599.06 \pm 29.45^{b}$ & $25.50 \pm 2.96^{\mathrm{ns}}$ \\
\hline $\mathrm{Og} \times \mathrm{R}_{4}$ & $10.02 \pm 0.78^{c}$ & $21.26 \pm 2.47^{b}$ & $121.04 \pm 5.95^{\mathrm{a}}$ & $1442.24 \pm 167.31^{a}$ & $21.08 \pm 2.56^{\mathrm{ns}}$ \\
\hline $\mathrm{C} \times \mathrm{R}_{4}$ & $29.28 \pm 3.97^{a}$ & $24.28 \pm 2.95^{a b}$ & $77.90 \pm 9.04^{b}$ & $928.62 \pm 112.65^{b}$ & $18.88 \pm 1.07^{\mathrm{ns}}$ \\
\hline $\mathrm{Ch} \times \mathrm{R}_{5}$ & $8.82 \pm 0.49 \mathrm{ab}$ & $12.16 \pm 0.69^{b}$ & $31.66 \pm 3.84^{c}$ & $578.28 \pm 32.80^{b}$ & $12.28 \pm 0.72^{b}$ \\
\hline $\mathrm{Mo} \times \mathrm{R}_{5}$ & $12.42 \pm 1.68^{\mathrm{a}}$ & $15.18 \pm 1.26^{\mathrm{ab}}$ & $87.14 \pm 4.94^{\mathrm{a}}$ & $1017.68 \pm 69.65^{a}$ & $17.78 \pm 1.57^{\mathrm{a}}$ \\
\hline $\mathrm{Og} \times \mathrm{R}_{5}$ & $6.42 \pm 0.36^{b}$ & $18.22 \pm 1.61^{\mathrm{a}}$ & $44.00 \pm 2.59^{c}$ & $584.22 \pm 28.72^{b}$ & $10.08 \pm 0.79^{b}$ \\
\hline $\mathrm{C} \times \mathrm{R}_{5}$ & $5.20 \pm 0.44^{b}$ & $17.20 \pm 1.34^{\mathrm{ab}}$ & $62.48 \pm 3.49^{b}$ & $486.24 \pm 56.41^{b}$ & $8.98 \pm 1.21^{b}$ \\
\hline $\mathrm{Ch} \times \mathrm{R}_{6}$ & $5.20 \pm 0.46^{b}$ & $24.28 \pm 3.29^{b}$ & $40.92 \pm 3.45^{b}$ & $296.22 \pm 35.93^{b}$ & $14.48 \pm 1.21^{b}$ \\
\hline $\mathrm{Mo} \times \mathrm{R}_{6}$ & $7.62 \pm 0.60^{b}$ & $37.44 \pm 2.09^{a}$ & $124.12 \pm 8.50^{\mathrm{a}}$ & $806.88 \pm 67.13^{a}$ & $24.40 \pm 2.15^{\mathrm{a}}$ \\
\hline $\mathrm{Og} \times \mathrm{R}_{6}$ & $14.84 \pm 2.01^{\mathrm{a}}$ & $30.36 \pm 2.56^{\mathrm{ab}}$ & $25.50 \pm 1.25^{\mathrm{b}}$ & $198.24 \pm 17.45^{b}$ & $11.18 \pm 0.88^{b}$ \\
\hline $\mathrm{C} \times \mathrm{R}_{6}$ & $13.64 \pm 1.2^{\mathrm{a}}$ & $33.38 \pm 2.28^{a b}$ & $148.78 \pm 17.26^{a}$ & $227.94 \pm 17.84^{b}$ & $11.18 \pm 1.51^{b}$ \\
\hline $\mathrm{Ch} \times \mathrm{R}_{7}$ & $17.24 \pm 0.96^{b}$ & $30.36 \pm 1.49^{b}$ & $37.82 \pm 4.59 \mathrm{bc}$ & $602.02 \pm 81.54^{a}$ & $33.20 \pm 1.85^{\mathrm{a}}$ \\
\hline $\mathrm{Mo} \times \mathrm{R}_{7}$ & $46.14 \pm 3.89^{a}$ & $51.58 \pm 5.99^{a}$ & $56.32 \pm 3.20^{b}$ & $322.94 \pm 18.04^{b}$ & $23.30 \pm 1.96^{b}$ \\
\hline $\mathrm{Og} \times \mathrm{R}_{7}$ & $16.04 \pm 1.10^{b}$ & $27.32 \pm 2.14^{b}$ & $105.64 \pm 6.22^{\mathrm{a}}$ & $331.86 \pm 27.97^{b}$ & $15.58 \pm 1.06^{c}$ \\
\hline $\mathrm{C} \times \mathrm{R}_{7}$ & $14.84 \pm 0.73^{b}$ & $44.50 \pm 6.03^{a b}$ & $34.74 \pm 2.72^{\mathrm{c}}$ & $121.06 \pm 8.29^{c}$ & $6.78 \pm 0.34^{\mathrm{d}}$ \\
\hline $\mathrm{Ch} \times \mathrm{R}_{8}$ & $4.00 \pm 0.22^{b}$ & $27.32 \pm 2.27^{b}$ & $31.66 \pm 4.29^{c}$ & $275.44 \pm 13.54 \mathrm{ab}$ & $12.28 \pm 1.43^{b}$ \\
\hline $\mathrm{Mo} \times \mathrm{R}_{8}$ & $5.20 \pm 0.44^{b}$ & $47.54 \pm 4.18^{\mathrm{a}}$ & $130.30 \pm 7.28^{a}$ & $325.92 \pm 37.81^{a}$ & $22.20 \pm 2.69^{a}$ \\
\hline $\mathrm{Og} \times \mathrm{R}_{8}$ & $11.22 \pm 0.77^{\mathrm{a}}$ & $36.42 \pm 2.85^{a b}$ & $96.38 \pm 8.12^{b}$ & $385.30 \pm 46.74^{\mathrm{a}}$ & $10.08 \pm 0.57^{b}$ \\
\hline $\mathrm{C} \times \mathrm{R}_{8}$ & $10.02 \pm 0.49^{a}$ & $48.56 \pm 6.58^{a}$ & $59.40 \pm 4.07^{c}$ & $138.86 \pm 7.88^{b}$ & $11.18 \pm 0.66^{b}$ \\
\hline $\mathrm{Ch} \times \mathrm{R}_{9}$ & $24.46 \pm 2.84^{\mathrm{a}}$ & $28.32 \pm 1.58^{\mathrm{a}}$ & $71.74 \pm 5.97 \mathrm{ab}$ & $355.60 \pm 20.95^{\mathrm{ns}}$ & $22.20 \pm 1.74^{\mathrm{ns}}$ \\
\hline $\mathrm{Mo} \times \mathrm{R}_{9}$ & $17.24 \pm 2.09 \mathrm{ab}$ & $26.30 \pm 2.22 \mathrm{ab}$ & $96.38 \pm 8.48^{\mathrm{a}}$ & $257.62 \pm 22.68^{\mathrm{ns}}$ & $27.70 \pm 3.75^{\mathrm{ns}}$ \\
\hline $\mathrm{Og} \times \mathrm{R}_{9}$ & $13.64 \pm 0.78^{b}$ & $19.22 \pm 1.32^{b}$ & $102.56 \pm 8.03^{a}$ & $379.36 \pm 29.69 \mathrm{~ns}$ & $18.88 \pm 1.06^{\mathrm{ns}}$ \\
\hline $\mathrm{C} \times \mathrm{R}_{9}$ & $13.64 \pm 0.80^{\mathrm{b}}$ & $31.36 \pm 1.54^{\mathrm{a}}$ & $50.16 \pm 6.79^{b}$ & $257.62 \pm 34.89 \mathrm{~ns}$ & $17.78 \pm 1.50^{\mathrm{ns}}$ \\
\hline $\mathrm{Ch} \times \mathrm{R}_{10}$ & $6.42 \pm 0.75^{c}$ & $22.26 \pm 2.58^{\mathrm{ns}}$ & $37.82 \pm 2.11^{\mathrm{ns}}$ & $269.50 \pm 22.42^{\mathrm{a}}$ & $15.58 \pm 1.06^{\mathrm{bc}}$ \\
\hline $\mathrm{Mo} \times \mathrm{R}_{10}$ & $12.42 \pm 1.51^{b}$ & $20.24 \pm 2.46^{\mathrm{ns}}$ & $31.66 \pm 2.67^{\mathrm{ns}}$ & $168.56 \pm 14.84^{b}$ & $24.40 \pm 1.20 \mathrm{ab}$ \\
\hline $\mathrm{Og} \times \mathrm{R}_{10}$ & $17.24 \pm 0.98^{a}$ & $19.22 \pm 1.09 \mathrm{~ns}$ & $31.66 \pm 2.17^{\mathrm{ns}}$ & $207.16 \pm 16.21^{\mathrm{ab}}$ & $33.20 \pm 3.85^{\mathrm{a}}$ \\
\hline $\mathrm{C} \times \mathrm{R}_{10}$ & $12.42 \pm 0.73^{b}$ & $22.26 \pm 1.31^{\mathrm{ns}}$ & $28.58 \pm 1.41^{\mathrm{ns}}$ & $138.86 \pm 18.81^{b}$ & $12.28 \pm 1.49^{\mathrm{c}}$ \\
\hline
\end{tabular}

Ch-Chemical; Mo-Biological; Og-Organic; C-Control; $\mathrm{R}_{1}-\mathrm{R}_{10}$ (first harvest time-the 10th harvesting time). Within each column, mean \pm standard deviation of each variable is reported in correspondence with each experimental treatment. Along each line, values followed by different letters are significantly different according to Tukey's test at $p \leq 0.05$. 
P-coumaric acid content widely varied from $4.00 \mu \mathrm{g} \cdot \mathrm{g}^{-1}$, in the case of the Ch treatment, from the eighth period $\left(R_{8}\right)$, to $46.14 \mu \mathrm{g} \cdot \mathrm{g}^{-1}$, in the case of fertilization with Mo from $R_{7}$.

Ferulic acid fluctuated from $12.16 \mu \mathrm{g} \cdot \mathrm{g}^{-1}$, in the case of $\mathrm{Ch}$ fertilization from $\mathrm{R}_{5}$, to $51.58 \mu \mathrm{g} \cdot \mathrm{g}^{-1}$, in the case of Mo from $\mathrm{R}_{7}$.

In addition, isoquercitrin was also significantly influenced by the fertilizer and harvesting period. It ranged in wide limits from $25.50 \mu \mathrm{g} \cdot \mathrm{g}^{-1}$, in the case of the $\mathrm{Og}$ fertilization, from $\mathrm{R}_{6}$, to $148.78 \mu \mathrm{g} \cdot \mathrm{g}^{-1}$, in the case of the control, which was also from $R_{6}$.

The values of rutoside fluctuated from $121.06 \mu \mathrm{g} \cdot \mathrm{g}^{-1}$ in the case of the control from $\mathrm{R}_{7}$ to 1442.24 $\mu \mathrm{g} \cdot \mathrm{g}^{-1}$ in the case of $\mathrm{Og}$ fertilization from the $\mathrm{R}_{4}$ harvest time.

The content of quercetrol ranged from $6.78 \mu \mathrm{g} \cdot \mathrm{g}^{-1}$ in the case of the control of $R_{7}$ to $33.20 \mu \mathrm{g} \cdot \mathrm{g}^{-1}$ in the case of the $\mathrm{Ch}$ treatment of $\mathrm{R}_{7}$ and $\mathrm{Og}$ from $\mathrm{R}_{10}$.

The content of biologically active compounds depends mainly on the cultivation method as well as cultivar and harvest time [49]. Many studies indicate that organic farming systems have a significant impact on the quality of strawberries produced, such as the use of organic and biological fertilization [50,51].

The fertilization treatments significantly influenced the number of petioles rhubarb per plant, their average weight per plant, the average weight per plant, and the yield dynamics (Table 6).

Table 6. Influence of fertilization on some production indicators $(n=3)$.

\begin{tabular}{ccccc}
\hline \multirow{2}{*}{ Fertilization } & $\begin{array}{c}\text { Average Number } \\
\text { of Stalks per Plant }\end{array}$ & $\begin{array}{c}\text { Average Weight } \\
\text { per Plant (g) }\end{array}$ & $\begin{array}{c}\text { Average Weight of } \\
\text { Stalks per Plant (g) }\end{array}$ & $\begin{array}{c}\text { Yield } \\
\left(\mathbf{t} \cdot \mathbf{h a}^{-\mathbf{1}} \text { ) }\right.\end{array}$ \\
\cline { 2 - 5 } & $\mathbf{n s}$ & $\mathbf{n s}$ & $\mathbf{n s}$ & $\mathbf{n s}$ \\
\hline Ch & $11.14 \pm 0.53$ & $443.8 \pm 10.77$ & $41.07 \pm 1.43$ & $59.16 \pm 5.21$ \\
Mo & $9.32 \pm 0.32$ & $368.80 \pm 13.82$ & $42.92 \pm 1.42$ & $49.16 \pm 3.85$ \\
Og & $10.22 \pm 0.06$ & $395.20 \pm 19.14$ & $40.31 \pm 1.17$ & $52.68 \pm 7.13$ \\
C & $9.22 \pm 0.47$ & $354.60 \pm 6.86$ & $39.11 \pm 1.05$ & $47.27 \pm 2.64$ \\
\hline
\end{tabular}

$\mathrm{Ch}-$ Chemical; Mo-Biological; $\mathrm{Og}$-Organic; C-Control. Within each column, the mean \pm standard deviation of each variable is reported in correspondence with each experimental treatment. Along each line, values followed by different letters are significantly different according to Tukey's test at $p \leq 0.05$, ns-no statistically significant difference.

The number of petioles per plant ranged from $9.2^{2}$, in the case of the control plant, to 11.14 , in the case of $\mathrm{Ch}$.

The average weight of the petioles per plant was not significantly influenced by fertilization. However, this ranged from $39.11 \mathrm{~g} \cdot$ plant $^{-1}$, in the case of the control plant, to $42.92 \mathrm{~g} \cdot$ plant $^{-1}$, in the case of Mo.

The total yield ranged from $47.27 \mathrm{t} \cdot \mathrm{ha}^{-1}$, in the case of the unfermented treatment, to $59.16 \mathrm{t} \cdot \mathrm{ha} \mathrm{a}^{-1}$, in the case of $\mathrm{Ch}$, although the differences between treatments were not significant.

The influence of different types of fertilizers on production indicators has also been demonstrated in vegetable species such as Cynara cardunculus L. [52,53].

The total quantity of stalks ranged from $1199.75 \mathrm{~kg} \cdot \mathrm{ha}^{-1}$, in the case of $\mathrm{R}_{4}$, up to $8044.75 \mathrm{~kg} \cdot \mathrm{ha}^{-1}$, in the case of the first harvesting season $\left(\mathrm{R}_{1}\right)$ (Figure 1 ). The highest yields were recorded in the first three harvests and in the last four, whereas the lowest values were recorded in the first three eras, and respectively in the last four. The lowest values were recorded in the middle of the harvesting period $\left(R_{4}, R_{5}\right.$, and $\left.R_{6}\right)$. 


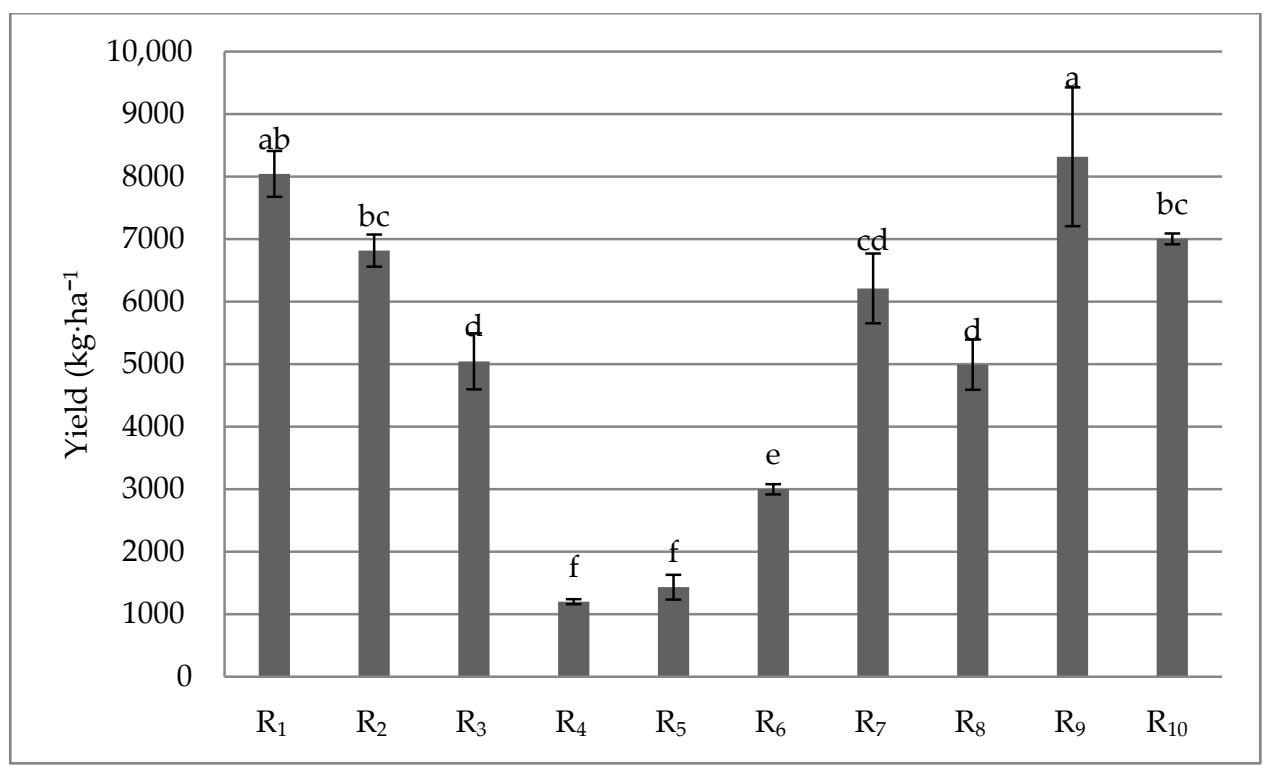

Figure 1. Yield dynamics influenced by harvest time $(n=3) . R_{1}-R_{10}$ (first harvest time-the 10th harvesting time). Within each column, the mean \pm standard deviation of each variable is reported in correspondence with each experimental treatment. Along each line, values followed by different letters are significantly different according to Tukey's test at $p \leq 0.05$.

Mouna et al. conducted a study on Salvia officinalis L., where phenophases led to higher production at the beginning of the harvesting period [54].

Fertilizer and harvesting times significantly influenced the dynamic yield of rhubarb petioles. Thus, the dynamic yield for the 40 experimental treatments varied widely from $560 \mathrm{~kg} \cdot \mathrm{ha}^{-1}$, in the case of the control at $\mathrm{R}_{4}$, up to $11,997 \mathrm{~kg} \cdot \mathrm{ha}^{-1}$, in the case of chemical fertilization $(\mathrm{Ch})$ from the ninth harvest $\left(R_{9}\right)$. Highest values were recorded under $C h$ fertilization at $R_{7}$ and that with $O g$ from $R_{9}$, which showed positive increases, compared to the control from the fourth harvest time $\left(R_{4}\right)$ (Table 7$)$.

Table 7. Interaction between harvest time and fertilization on dynamic yield $\left(\mathrm{kg}^{\mathrm{h}} \mathrm{ha}{ }^{-1}\right)(\mathrm{n}=3)$.

\begin{tabular}{|c|c|c|c|c|}
\hline \multirow{2}{*}{ Harvest Time } & \multicolumn{4}{|c|}{ Treatment } \\
\hline & Ch & Mo & Og & $\mathrm{C}$ \\
\hline $\mathrm{R}_{1}$ & $7278 \pm 498.1^{\mathrm{b}-\mathrm{g}}$ & $7838 \pm 385.37^{b-e}$ & $8665 \pm 1005.19 b c$ & $8398 \pm 1018.76^{b d}$ \\
\hline $\mathrm{R}_{2}$ & $5865 \pm 332.67^{c-i}$ & $5865 \pm 487.97^{\mathrm{c}-\mathrm{i}}$ & $7438 \pm 654.77^{b-f}$ & $8105 \pm 634.26^{\mathrm{b}-\mathrm{e}}$ \\
\hline $\mathrm{R}_{3}$ & $5092 \pm 689.69^{\mathrm{e}-1}$ & $5519 \pm 308.34^{c-j}$ & $4212 \pm 355.01 \mathrm{~g}-\mathrm{n}$ & $5359 \pm 366.77^{\mathrm{d}-\mathrm{k}}$ \\
\hline $\mathrm{R}_{4}$ & $800 \pm 39.33^{o-p}$ & $2106 \pm 244.31^{1-p}$ & $1333 \pm 161.71^{\mathrm{n}-\mathrm{p}}$ & $560 \pm 31.76 \mathrm{p}$ \\
\hline $\mathrm{R}_{5}$ & $1013 \pm 79.27^{o-p}$ & $2266 \pm 306.92^{k-p}$ & $1600 \pm 89.39 \mathrm{~m}-\mathrm{p}$ & $853 \pm 71.89$ op \\
\hline $\mathrm{R}_{6}$ & $3066 \pm 209.84^{i-p}$ & $2453 \pm 120.61^{j-p}$ & $3946 \pm 328.31^{\mathrm{h}-\mathrm{o}}$ & $2533 \pm 222.98^{j-p}$ \\
\hline $\mathrm{R}_{7}$ & $11864 \pm 928.43^{\mathrm{a}}$ & $2853 \pm 386.42^{i-p}$ & $5199 \pm 290.46^{\mathrm{e}-1}$ & $4932 \pm 415.7^{\mathrm{e}-1}$ \\
\hline $\mathrm{R}_{8}$ & $6612 \pm 452.52^{b-h}$ & $5305 \pm 260.83^{d-k}$ & $2800 \pm 324.82^{i-p}$ & $5252 \pm 637.12^{\mathrm{d}-1}$ \\
\hline $\mathrm{R}_{9}$ & $11997 \pm 1624.93^{a}$ & $6985 \pm 390.24^{\mathrm{b}-\mathrm{h}}$ & $9758 \pm 822.45^{a b}$ & $4532 \pm 310.17^{\mathrm{f}-\mathrm{m}}$ \\
\hline $\mathrm{R}_{10}$ & $5572 \pm 273.96^{c-j}$ & $7971 \pm 924.68^{b-e}$ & $7731 \pm 937.84^{\mathrm{b}-\mathrm{e}}$ & $6745 \pm 382.59^{b-h}$ \\
\hline
\end{tabular}

Ch-Chemical; Mo-Biologic; Og-Organic; C-Control; $\mathrm{R}_{1}-\mathrm{R}_{10}$ (first harvest time-the 10th harvesting time). Within each column, the mean \pm standard deviation of each variable is reported in correspondence with each experimental treatment. Along each line, values followed by different letters are significantly different according to Tukey's test at $p \leq 0.05$.

Corroborating the dynamics of the production with the climatic conditions, we can say that the production at the perennial plants has its peak at the beginning of the vegetation period when the average temperature increases above $5{ }^{\circ} \mathrm{C}$ and the soil has sufficient accumulated humidity from the winter season. The vegetative buds bloom in greater numbers, but they grow slower, they are more succulent, the petioles reach the normal size in a longer period, and they accumulate water in greater 
quantity, when the harvest is bigger. After harvesting and in more arid onditions, the plants grow slower; they recover in a longer period, because they start from dormant buds or those that appear in the respective year of culture.

The application of chemical fertilizers, which have high solubility, made the production from the second part of the vegetation period bigger, and between the control and the types of fertilization at the beginning of the year, there were not very big differences, because the first petioles initially grow from the accumulated reserves in rhizomes in the previous year.

\section{Materials and Methods}

\subsection{Plant Material and Growth Conditions}

A research study was carried out in 2017 at "V. Adamachi" Experimental Station of the Agronomic University of Iasi $\left(47^{\circ} 19^{\prime} 25^{\prime \prime} \mathrm{N}, 27^{\circ} 54^{\prime} 99^{\prime \prime} \mathrm{E}, 150 \mathrm{~m}\right.$ a.s.1.) on rhubarb (Rheum rhabarbarum L.) using root cuttings of the Victoria cv. The cambic chernozem soil is characterized by a medium fertility, with $3.1 \%$ organic matter, $32 \%$ of clay and $\mathrm{pH}=6.6$. During the experimental period, the average temperature was $18.54{ }^{\circ} \mathrm{C}$, the precipitation was $293.5 \mathrm{~mm}$, and the relative humidity of the air was $66.8 \%$ (Table 8).

Table 8. Temperature, rainfall, relative humidity, and sunlight during the experiment.

\begin{tabular}{ccccc}
\hline Month/Year & $\begin{array}{c}\text { Temperature } \\
\text { Average }\left({ }^{\circ} \mathbf{C}\right)\end{array}$ & $\begin{array}{c}\text { Total Rainfall } \\
(\mathbf{m m})\end{array}$ & $\begin{array}{c}\text { Relative Humidity } \\
\mathbf{( \% )}\end{array}$ & Sunlight (hours) \\
\hline April/2017 & 10.3 & 89.1 & 67 & 205.5 \\
May/2017 & 16.5 & 71.0 & 68 & 278.4 \\
June/2017 & 21.7 & 46.6 & 65 & 293.4 \\
July/2017 & 22.0 & 47.8 & 68 & 291.0 \\
August/2017 & 22.2 & 39.0 & 66 & 290.5 \\
\hline
\end{tabular}

The planting was practiced in 2012, with plants spaced $0.75 \mathrm{~m}$ along the rows, which were $1.00 \mathrm{~m}$ apart (density of 1.33 plants $\cdot \mathrm{m}^{-2}$ ). Due to the dry agricultural year, three irrigations were practiced, each with $250 \mathrm{~m}^{3} \cdot \mathrm{ha}^{-1}$, when the soil available water decreased below $80 \%$. Flowering stems were removed 4 to 5 days after planting in order to favor the development of the edible part [55]. During the vegetation period, two manual hoeings were performed between rows and plants. No phytosanitary treatments were performed for protecting plants against diseases and pests. The biometric and biochemical determinations were made in 2017 on a rhubarb crop set up by seedlings to the fifth year of harvest.

\subsection{Experimental Protocol}

Three types of fertilization were compared in a split plot design experiment with three replications. Chemical (NPK = 16-16-16), Mycorrhizal-based formulate (Micoseeds MB ${ }^{\circledR}$ ), and Organic (Orgevit ${ }^{\circledR}$ ) treatments were compared to an unfertilized control (C). Chemical NPK 16-16-16 was produced by Ameropa Company ${ }^{\circledR}$ (Romania), Micoseeds $\mathrm{MB}^{\circledR}$ was from MsBiotech (Italy), and Orgevit ${ }^{\circledR}$ was from MeMon BV (Netherlands). The biological product consists of an arbuscular mycorrhizal fungus (Glomus spp.), PGPR (Pseudomonas sp., Bacillus spp., Streptomyces sp.), and a fungus (Trichoderma sp.) in different proportions. Organic fertilizer is chicken manure formulate with pH 7, 4\% N, 2.5\% P2O5, 2.3\% K2O, 1\% MgO, 0.02\% Fe, 0.01\% Mn, 0.01\% B, 0.01\% Zn, 0.001\% Cu, and 0.001\% $\mathrm{Mo}$. All fertilizers were supplied to the soil. Thus, the $\mathrm{Ch}$ fertilizer was applied in an amount of $425 \mathrm{~kg}$ $\mathrm{ha}^{-1}$. The product beneficial microorganisms-based Micoseed MB (Mo) was used in the dose of $60 \mathrm{~kg}$ $\mathrm{ha}^{-1}$. Og was applied at the dose of $2400 \mathrm{~kg} \mathrm{ha}^{-1}$. Ch and $\mathrm{Og}$ fertilizers were supplied after the first petiole harvest $(03.04)$ in five stages $\left(04.04,28.04,12.05,26.05\right.$, and 09.06); Micoseeds $\mathrm{MB}^{\circledR}$ was applied in two stages, the first before planting (16.03) and the second one day after the first harvest (04.04) according to producer recommendations. For the determination of the doses of the fertilizers Og and 
$\mathrm{Ch}$, the chemical composition of each product was taken into account, and for the $\mathrm{Og}$, it was considered that $70 \%$ of the active substance of the product is assimilated in the first year after application.

Biometric and chemical determinations were performed at 10 harvest times: $R_{1}: 03.04, R_{2}: 11.04$, $\mathrm{R}_{3}: 19.04, \mathrm{R}_{4}: 03.05, \mathrm{R}_{5}: 10.05, \mathrm{R}_{6}: 22.05, \mathrm{R}_{7}: 07.06, \mathrm{R}_{8}: 23.06, \mathrm{R}_{9}: 19.07$, and $\mathrm{R}_{10}: 12.08$.

\subsection{Biometric Measurements}

From the field of research were collected stalks from each plant from the four variants taken in the experiment. For each variant, we determined the average quantities obtained by measuring the weight with the electronic scale. Petioles with a minimum diameter of 10-12 mm and a length of 25-30 cm were harvested. In the laboratory, weighing was performed on the analytical balance to determine the average weight of petioles per plant. To determine the length of the stalks, the measurements were made with the graduated ruler, with the unit of measure in centimeters, and the thickness of the petioles was determined with the electronic chisel (mm).

\subsection{Samples Preparation}

In order to prepare the material for the laboratory analyses, 10 stalks from each repetition were selected randomly for a total of 40 pieces. The petioles were cut into $1 \mathrm{~cm}$ fragments for drying under normal weather conditions. The drying was carried out on a Sanyo oven, type MOV-112F, at a temperature of $70{ }^{\circ} \mathrm{C}$ up to the total loss of water from the dry material in order to determine the quantity of water and the dry substance. The samples were crushed into small fragments of $0.1-1 \mathrm{~mm}$. The last step consisted in the packaging and labeling of variants in order to carry out laboratory analyses to determine the polyphenol content and antioxidant capacity in plants.

\subsection{HPLC-MS Analysis of Phenolic Compounds}

In this application, the presence and content of different phenolic compounds in $70 \%$ ethanolic extracts were studied using an HPLC-MS, method which allows the simultaneous detection of several phenolic compounds with a single column pass [56].

The identification and quantification of polyphenolic compounds was carried out using an Agilent Technologies 1100 HPLC Series system (Agilent, Santa Clara, CA, USA) equipped with a G13311A binary gradient pump, G1322A degasser, column thermostat, G1316A UV detector, and G1313A autosampler. The HPLC system was coupled with an Agilent 1100 mass spectrometer (LC/MSD Ion Trap SL). For the separation, a reverse-phase analytical column was employed (Zorbax SB-C18 $100 \times 3.0 \mathrm{~mm}$ i.d., $3.5 \mu \mathrm{m}$ particle) and the work temperature was set at $48^{\circ} \mathrm{C}$. The detection of the compounds was performed in both UV and MS mode [57-59]. The UV detector was set at $330 \mathrm{~nm}$ until $17.5 \mathrm{~min}$, and then at $370 \mathrm{~nm}$. The MS system was operated using an electrospray ion source in the negative mode. ChemStation and DataAnalysis software from Agilent were used for processing the chromatographic data. The mobile phase was a binary gradient: methanol and acetic acid $0.1 \%(v / v)$. The elution started with a linear gradient, beginning with $5 \%$ methanol and ending at $42 \%$ methanol, for $35 \mathrm{~min}$; then, it had $42 \%$ methanol for the next $3 \mathrm{~min}$. The flow rate was $1 \mathrm{~mL} \cdot \mathrm{min}^{-1}$, and the injection volume was $5 \mu \mathrm{L}[60,61]$.

\subsection{Antioxidant Activity Test}

The rhubarb stalks' antioxidant capacity was assessed in terms of radical scavenging activity, following the procedure described by Re et al. [62] with slight modifications [63]. In this respect, 500 $\mu \mathrm{L}$ aliquot of the extract or Trolox standard was added to $1 \mathrm{~mL}$ of DPPH methanol solution $\left(74 \mathrm{mg} \cdot \mathrm{L}^{-1}\right)$. A daily prepared solution of 2,2-diphenyl-1-picryl-hydrazylhydrate (DPPH) showed a final absorption at $520 \mathrm{~nm}$ of $1.8 \mathrm{AU}$. The mixture was shaken and allowed to stand for $1 \mathrm{~h}$ at room temperature; then, the absorption was measured at $520 \mathrm{~nm}$ in a Lambda 25 spectrophotometer. The antiradical activity of the sample is inversely correlated with its purple color intensity. Aqueous solutions of Trolox at various concentrations were used for calibration $\left(0.15-1.15 \mathrm{mmol} \cdot \mathrm{L}^{-1}\right)$. The results were expressed as $\mu \mathrm{mol}$ 
equivalents of Trolox (an analog of vitamin E) per g of sample (TEAC-Trolox Equivalent Antioxidant Capacity) [64].

\subsection{Statistical Analysis}

Data statistical processing was carried out by one-way and two-way ANOVA, and mean separations were performed through Tukey's test using a SPSS version 21, referring to $p \leq 0.05$ probability level.

\section{Conclusions}

The present study confirms that fertilizer management method may have a significant impact on the phenolic composition of rhubarb. The fact that there are qualitative variations between polyphenols at the same harvest date, under same environmental conditions, on the same cultivar indicates that they are influenced by the treatment used.

However, in addition, harvesting time under climatic conditions has an important effect on the quality and quantity of bioactive compounds.

The research shows that the biological fertilizer had a positive effect on the total phenol content, directly influencing the antioxidant capacity from rhubarb, compared to the chemical and organic fertilizers, which are very important in the human diet.

Biological fertilization provides satisfactory nutritional conditions for the accumulation of ferulic acid, p-coumaric acid, isoquercitrin, and quercetrol compared with rutoside, which accumulates in the highest quantities under organic fertilization. Polyphenolic compounds accumulate in petiols of rhubarb as follows: rutozide $>$ isoquercitrin $>$ ferulic acid $>$ quercetrol $>$ p-coumaric acid.

Chemical fertilization provided the highest yields, regardless of the harvesting period, but the differences with respect to organic and biological treatments were not, which means that there are favorable conditions for using the two fertilizers in sustainable agriculture, without restriction.

The treatments carried out and the harvesting period in accordance with the climatic conditions emphasize that there are the premises of promoting organic and biological treatments for a type of non-polluting, sustainable agriculture.

Author Contributions: V.S. and A.C. provide the research idea, protocol design and wrote the manuscript, critically commented on the manuscript draft, N.M. and T.S.; statistical analysis, M.B.; manage analyses, L.V.; experimental driving, A.C. and G.C.T. All authors reviewed, edited, and discussed this review. All authors have read and agreed to the published version of the manuscript.

Funding: This research received no external funding.

Acknowledgments: The authors wish to thank the management of "Ion Ionescu de la Brad" University of Agricultural Sciences and Veterinary Medicine for the financial support of the experiences and Delia Achitei the help given for data collection.

Conflicts of Interest: The authors declare no conflict of interest.

\section{References}

1. Jintao, X.; Yongli, S.; Liming, Y.; Quanwei, Y.; Chunyan, L.; Xingyy, C.; Yun, J. Near-infrared spectroscopy for rapid and simultaneous determination offive main active components in rhubarb of different geographical originsand processing. Spectrochim. Acta A Mol. Biomol. Spectrosc. 2018, 205, 419-427. [CrossRef] [PubMed]

2. Ye, M.; Han, J.; Chen, H.; Zheng, J.; Guo, D. Analysis of phenolic compounds in rhubarbs using liquid chromatography coupled with electrospray ionization mass spectrometry. J. Am. Soc. Mass Spectrom. 2007, 18, 82-91. [CrossRef] [PubMed]

3. Weaver, C.M.; Heaney, R.P.; Nickel, K.P.; Packard, P.I. Calcium bioavailability from high oxalate vegetables: Chinese vegetables, sweet potatoes and rhubarb. J. Food Sci. 1997, 62, 524-525. [CrossRef]

4. Zhou, K.; Yu, L. Total phenolic content and antioxidant properties of commonly consumed vegetables grown in California. Lwt-Food Sci. Technol. 2006, 39, 1155-1162. [CrossRef]

5. Takeoka, G.R.; Dao, L.; Harden, L.; Pantoja, A.; Kuhl, J.C. Antioxidant activity, phenolic and anthocyanin contents of various rhubarb (Rheum spp.) varieties. Int. J. Food Sci. Technol. 2012, 48, 172-178. [CrossRef] 
6. Huang, Q.; Lu, G.; Shen, H.M.; Chung, M.C.M.; Ong, C.N. Anti-cancer properties of anthraquinones from rhubarb. Med. Res. Rev. 2017, 27, 609-630. [CrossRef]

7. Raudsepp, P.; Koskar, J.; Anton, D.; Meremäea, K.; Kapp, K.; Laurson, P.; Bleive, U.; Kaldmäe, H.; Roasto, M.; Püssa, T. Antibacterial and antioxidative properties of different parts of garden rhubarb, black currant, chokeberry and blue honeysuckle. J. Sci. Food Agric. 2019, 99, 2311-2320. [CrossRef]

8. Mi, W.H.; Wu, L.H.; Brookes, P.C.; Liu, Y.L.; Zhang, X.; Yang, X. Changes in soil organic carbon fractions under integrated management systems in a low-productivity paddy soil given different organic amendments and chemical fertilizers. Soil Till. Res. 2016, 163, 64-70. [CrossRef]

9. Nicoulaud, B.A.L.; Bloom, A.J. Absorption and assimilation of foliarly applied urea in tomato. J. Am. Soc. Hortic. Sci. 1996, 121, 1117-1121. [CrossRef]

10. Cojocaru, A.; Munteanu, N.; Petre, B.A.; Stan, T.; Teliban, G.C.; Vintu, C.; Stoleru, V. Biochemical and production of rhubarb under growing technological factors. Rev. Chim.-Bucharest. 2019, 70, 2000-2003. [CrossRef]

11. Stoleru, V.; Munteanu, N.; Istrate, A. Perception towards organic vs. conventional products in Romania. Sustainability 2019, 11, 2394. [CrossRef]

12. Conti, S.; Villari, G.; Faugno, S.; Melchionna, G.; Somma, S.; Caruso, G. Effects of organic vs. conventional farming system on yield and quality of strawberry grown as an annual or biennial crop in southern Italy. Sci. Hortic. 2014, 180, 63-71. [CrossRef]

13. Kalisz, S.; Oszmiański, J.; Kolniak-Ostek, J.; Grobelna, A.; Kieliszek, M.; Cendrowski, A. Effect of a variety of polyphenols compounds and antioxidant properties of rhubarb (Rheum rhabarbarum). Lwt-Food Sci. Technol. 2020, 118, 108775. [CrossRef]

14. Skrovankova, S.; Sumczynski, D.; Mlcek, J.; Jurikova, T.; Sochor, J. Bioactive compounds and antioxidant activity in different types of berries. Int. J. Mol. Sci. 2015, 16, 24673-24706. [CrossRef] [PubMed]

15. He, Z.H.; He, M.F.; Ma, S.C.; But, P.P.H. Anti-angiogenic effects of rhubarb and its anthraquinone derivatives. J. Ethnopharmacol. 2009, 121, 313-317. [CrossRef] [PubMed]

16. Neyrinck, A.M.; Etxeberria, U.; Taminiau, B.; Daube, G.; Van, H.M.; Everard, A.; Cani, P.D.; Bindels, L.B.; Delzenne, N.M. Rhubarb extract prevents hepatic inflammation induced by acute alcohol intake, an effect related to the modulation of the gut microbiota. Mol. Nutr. Food Res. 2016, 61, 1500899. [CrossRef] [PubMed]

17. Püssa, T.; Raudsepp, P.; Kuzina, K.; Raal, A. Polyphenolic composition of roots and petioles of Rheum rhaponticum L. Phytochem. Anal. 2009, 20, 98-103. [CrossRef]

18. Dregus, M.; Engel, K.H. Volatile constituents of uncooked rhubarb (Rheum rhabarbarum L.) stalks. J. Agric. Food Chem. 2003, 51, 6530-6536. [CrossRef]

19. Zhang, L.; Ravipati, A.S.; Koyyalamudi, S.R.; Jeong, S.C.; Reddy, N.; Smith, P.T.; Bartlett, J.; Shanmugam, K.; Münch, G.; Wu, M.J. Antioxidant and anti-inflammatory activities of selected medicinal plants containing phenolic and flavonoid compounds. J. Agric. Food Chem. 2001, 59, 12361-12367. [CrossRef]

20. Santos, E.R.M.; Oliveira, H.N.M.; Oliveira, E.J.; Azevedo, S.H.G.; Jesus, A.A.; Medeiros, A.M.; Dariva, C.; Sousa, E.M.B.D. Supercritical fluid extraction of Rumex acetosa L. roots: Yield, composition, kinetics, bioactive evaluation and comparison with conventional techniques. J. Supercrit. Fluid. 2017, 122, 1-9. [CrossRef]

21. Tolra, R.P.; Poschenrieder, C.; Luppi, B.; Barcelo, J. Aluminium-induced changes in the profiles of both organic acids and phenolic substances underlie Al tolerance in Rumex acetosa L. Environ. Exp. Bot. 2005, 54, 231-238. [CrossRef]

22. Kucekova, Z.; Mlcek, J.; Humpolicek, P.; Rop, O.; Valasek, P.; Saha, P. Phenolic compounds from Allium schoenoprasum, Tragopogon pratensis and Rumex acetosa and their antiproliferative effects. Molecules 2011, 16, 9207-9217. [CrossRef]

23. Savran, A.; Zengin, G.; Aktumsek, A.; Mocan, A.; Glamoclija, J.; Ciric, A.; Sokovic, M. Phenolic compounds and biological effects of edible Rumex scutatus and Pseudosempervivum sempervivum: Potential sources of natural agents with health benefits. Food Funct. 2016, 7, 3252-3262. [CrossRef]

24. Reigosa, M.J.; Souto, X.C.; Gonzalez, L. Effect of phenolic compounds on the germination of six weeds species. Plant Growth Regul. 1999, 28, 83-88. [CrossRef]

25. Coruh, I.; Gormez, A.A.; Ercisli, S.; Sengul, M. Total phenolic content, antioxidant, and antibacterial activity of Rumex crispus grown wild in Turkey. Pharm. Biol. 2008, 46, 634-638. [CrossRef]

26. Elzaawely, A.A.; Xuan, T.D.; Tawata, S. Antioxidant and antibacterial activities of Rumex japonicus Houtt. aerial parts. Biol. Pharm. Bull. 2005, 28, 2225-2230. [CrossRef] 
27. Sahreen, S.; Khan, M.R.; Khan, R.A. Phenolic compounds and antioxidant activities of Rumex hastatus D. Don. leaves. J. Med. Plant Res. 2011, 5, 2755-2765.

28. Ahmad, S.; Ullah, F.; Ayaz, M.; Sadiq, A.; Imran, M. Antioxidant and anticholinesterase investigations of Rumex hastatus D. Don: Potential effectiveness in oxidative stress and neurological disorders. Biol. Res. 2015, 48, 20. [CrossRef]

29. Makkar, H.P.S.; Singh, B.; Vats, S.K.; Sood, R.P. Total phenols, tannins and condensed tannins in different parts of Rumex hastatus. Bioresour. Technol. 1993, 45, 69-71. [CrossRef]

30. Jimoh, F.O.; Adedapo, A.A.; Aliero, A.A.; Afolayan, A.J. Polyphenolic contents and biological activities of Rumex ecklonianus. Pharm Biol. 2008, 46, 333-340. [CrossRef]

31. Mhalla, D.; Bouaziz, A.; Ennouri, K.; Chawech, R.; Smaoui, S.; Jarraya, R.; Tounsi, S.; Trigui, M. Antimicrobial activity and bioguided fractionation of Rumex tingitanus extracts for meat preservation. Meat Sci. 2017, 125, 22-29. [CrossRef] [PubMed]

32. Taulavuori, K.; Pyysalo, A.; Taulavuori, E.; Julkunen-Tiitto, R. Responses of phenolic acid and flavonoid synthesis to blue and blue-violet light depends on plant species. Environ. Exp. Bot. 2018, 150, 183-187. [CrossRef]

33. Isbilir, S.S.; Sagiroglu, A. Total phenolic content, antiradical and antioxidant activities of wild and cultivated Rumex acetosella L. extracts. Biol. Agric. Hortic. 2013, 29, 219-226. [CrossRef]

34. Spinola, V.; Llorent-Martinez, E.J.; Castilho, P.C. Antioxidant polyphenols of Madeira sorrel (Rumex maderensis): How do they survive to in vitro simulated gastrointestinal digestion? Food Chem. 2018, 259, 105-112. [CrossRef]

35. Feduraev, P.; Chupakhina, G.; Maslennikov, P.; Tacenko, N.; Skrypnik, L. Variation in phenolic compounds content and antioxidant activity of different plant organs from Rumex crispus L. and Rumex obtusifolius L. at different growth stages. Antioxidants 2019, 8, 237. [CrossRef] [PubMed]

36. Celebi, S.Z.; Demir, S.; Celebi, R.; Durak, E.D.; Yilmaz, I.H. The effect of Arbuscular Mycorrhizal Fungi (AMF) applications on the silage maize (Zea mays L.) yield in different irrigation regimes. Eur. J. Soil Biol. 2010, 46, 302-305. [CrossRef]

37. Avio, L.; Sbrana, C.; Giovannetti, M.; Frassinetti, S. Arbuscular mycorrhizal fungi affect total phenolics content and antioxidant activity in leaves of oak leaf lettuce varieties. Sci. Hortic. 2017, 224, $265-271$. [CrossRef]

38. Bello, O.M.; Fasinu, P.S.; Bello, O.E.; Ogbesejana, A.B.; Adetunji, C.O.; Dada, A.O.; Ibitoye, O.S.; Aloko, S.; Oguntoye, O.S. Wild vegetable Rumex acetosa Linn.: Its ethnobotany, pharmacology and phytochemistry-A review. S. Afr. J. Bot. 2019, 125, 149-160. [CrossRef]

39. Christian, K.R.; Jackson, J.C. Changes in total phenolic and monomeric anthocyanin composition and antioxidant activity of three varieties of sorrel (Hibiscus sabdariffa) during maturity. J. Food Compos. Anal. 2009, 22, 663-667. [CrossRef]

40. Ferrol, N.; Pérez-Tienda, J. Coordinated Nutrient Exchange in Arbuscular Mycorrhiza. In Mycorrhizas-Functional Processes and Ecological Impact; Azcón-Aguilar, C., Barea, J., Gianinazzi, S., Gianinazzi-Pearson, V., Eds.; Springer: Berlin/Heidelberg, Germany, 2009; pp. 73-87.

41. Solfanelli, C.; Poggi, A.; Loreti, E.; Alpi, A.; Perata, P. Sucrose-specific induction of the anthocyanin biosynthetic pathway in Arabidopsis. Plant. Physiol. 2006, 140, 637-646. [CrossRef]

42. Popovic, B.M.; Stajner, D.; Zdero-Pavlovic, R.; Tumbas-Saponjac, V.; Canadanovic-Brunet, J.; Orlovic, S. Water stress induces changes in polyphenol profile and antioxidant capacity in poplar plants (Populus spp.). Plant. Physiol. Biochem. 2016, 105, 242-250. [CrossRef]

43. Dimitriu, D.C.; Stoleru, V.; Corciova, A.; Vlase, L.; Stan, T.; Jitareanu, A.; Munteanu, N.; Rotaru, L.; Patras, A. P-coumaric acid content in sweet pepper under farming methods. Environ. Eng. Manag. J. 2016, 15, 1841-1848. [CrossRef]

44. Caruso, G.; De Pascale, S.; Cozzolino, E.; Cuciniello, A.; Cenvinzo, V.; Bonini, P.; Colla, G.; Rouphael, Y. Yield and nutritional quality of vesuvian piennolo tomato pdo as affected by farming system and biostimulant application. Agronomy 2019, 9, 505. [CrossRef]

45. Chanthini, K.M.P.; Stanley-Raja, V.; Thanigaivel, A.; Karthi, S.; Palanikani, R.; Sundar, N.S.; Sivanesh, H.; Soranam, R.; Senthil-Nathan, S. Sustainable agronomic strategies for enhancing the yield and nutritional quality of wild tomato, Solanum Lycopersicum (1) var Cerasiforme Mill. Agronomy 2019, 9, 311. [CrossRef] 
46. Kim, G.D.; Lee, Y.S.; Cho, J.Y.; Lee, Y.H.; Choi, K.J.; Lee, Y.; Han, T.H.; Lee, S.H.; Park, K.H.; Moon, J.H. Comparison of the content of bioactive substances and the inhibitory effects against rat plasma oxidation of conventional and organic hot peppers (Capsicum annuum L.). J. Agric. Food Chem. 2010, 58, 12300-12306. [CrossRef]

47. Wu, Y.; Zhao, C.Y.; Farmer, J.; Sun, J.D. Effects of bio-organic fertilizer on pepper growth and Fusarium wilt biocontrol. Sci. Hortic. 2015, 193, 114-120. [CrossRef]

48. Aliyu, L. Effect of organic and mineral fertilizers on growth, yield and composition of pepper (Capsicum annuum L.). Biol. Agric. Hortic. 2000, 18, 29-36. [CrossRef]

49. Ponder, A.; Hallmann, E. The effects of organic and conventional farm management and harvest time on the polyphenol content in different raspberry cultivars. Food Chem. 2019, 301, 125295. [CrossRef]

50. Crecente-Campo, J.; Nunes-Damaceno, M.; Romero-Rodriguez, M.A.; Vazquez-Oderiz, M.L. Color, anthocyanin pigment, ascorbic acid and total phenolic compound determination in organic versus conventional strawberries (Fragaria x ananassa Duch, cv Selva). J. Food Compos. Anal. 2012, 28, 23-30. [CrossRef]

51. Rawat, S.; Jugran, A.K.; Bhatt, I.D.; Rawal, R.S. Influence of the growth phenophases on the phenolic composition and anti-oxidant properties of Roscoea procera Wall. in western Himalaya. J. Food Sci. Technol. 2018, 55, 578-585. [CrossRef]

52. Francaviglia, R.; Bruno, A.; Falcucci, M.; Farina, R.; Renzi, G.; Russo, D.E.; Sepe, L.; Neri, U. Yields and quality of Cynara cardunculus L. wild and cultivated cardoon genotypes. A case study from a marginal land in Central Italy. Eur. J. Agron. 2016, 72, 10-19. [CrossRef]

53. Petropoulos, S.A.; Pereira, C.; Tzortzakis, N.; Barros, L.; Ferreira, I.C.F.R. Nutritional value and bioactive compounds characterization of plant parts from Cynara cardunculus L. (Asteraceae) cultivated in central Greece. Front. Plant. Sci. 2018, 9, 459. [CrossRef]

54. Farhat, M.B.; Jordan, M.J.; Chaouch-Hamada, R.; Landoulsi, A.; Sotomayor, J.A. Phenophase effects on sage (Salvia officinalis L.) yield and composition of essential oil. J. Appl. Res. Med. Aromat. Plants. 2016, 3, 87-93. [CrossRef]

55. Stoleru, V.; Munteanu, N.; Stan, T.; Ipatioaie, C.; Cojocaru, A.; Butnariu, M. Effects of production system on the content of organic acids in Bio rhubarb (Rheum rhabarbarum L.). Rom. Biotechnol. Lett. 2019, 24, 184-192. [CrossRef]

56. Mocan, A.; Vodnar, D.C.; Vlase, L.; Crișan, O.; Gheldiu, A.-M.; Crișan, G. Phytochemical Characterization of Veronica officinalis L., V. teucrium L. and V. orchidea Crantz from Romania and Their Antioxidant and Antimicrobial Properties. Int. J. Mol. Sci. 2015, 16, 21109-21127. [CrossRef]

57. Mocan, A.; Vlase, L.; Vodnar, D.C.; Bischin, C.; Hanganu, D.; Gheldiu, A.-M.; Oprean, R.; Silaghi-Dumitrescu, R.; Crișan, G. Polyphenolic content, antioxidant and antimicrobial activitiesof Lycium barbarum L. and Lycium chinense Mill. leaves. Molecules 2014, 19, 10056-10073. [CrossRef]

58. Vlase, L.; Benedec, D.; Hanganu, D.; Damian, G.; Csillag, I.; Sevastre, B.; Mot, A.C.; Silaghi-Dumitrescu, R.; Tilea, I. Evaluation of antioxidant and antimicrobial activities and phenolic profile for Hyssopus officinalis, Ocimum basilicum and Teucrium chamaedrys. Molecules 2014, 19, 5490-5507. [CrossRef]

59. Putnoky, S.; Caunii, A.; Butnariu, M. Study on the stability and antioxidant effect of the Allium ursinum watery extract. Chem. Cent. J. 2013, 7, 21. [CrossRef]

60. Lotfi, S.; Kordsardouei, H.; Oloumi, H. Study of total phenolic content and antioxidant capacity of the ethanolic extracts of two medicinal plants, Hibiscus sabdariffa L. and Amaranthus caudatus L. Banat's J. Biotechnol. 2019, 10, 66-74. [CrossRef]

61. Butnariu, M.; Caunii, A.; Putnoky, S. Reverse phase chromatographic behaviour of major components in Capsicum Annuum extract. Chem. Cent. J. 2012, 6, 146. [CrossRef]

62. Re, R.; Pellegrini, N.; Proteggente, A.; Pannala, A.; Yang, M.; Rice-Evans, C. Antioxidant activity applying an improved Abts radical cation decolorization assay. Free Radic. Biol. Med. 1999, 26, 1231-1237. [CrossRef]

63. Caruso, G.; Conti, S.; Villari, G.; Borrelli, C.; Melchionna, G.; Minutolo, M.; Russo, G.; Amalfitano, C. Effects of transplanting time and plant density on yield, quality and antioxidant content of onion (Allium cepa L.) in southern Italy. Sci. Hortic. 2014, 166, 111-120. [CrossRef]

64. Ouis, N.; Hariri, A. Phytochemical analysis and antioxidant activity of the flavonoids extracts from pods of Ceratonia siliqua L. Banat's J. Biotechnol. 2017, 8, 93-104. [CrossRef]

(C) 2020 by the authors. Licensee MDPI, Basel, Switzerland. This article is an open access article distributed under the terms and conditions of the Creative Commons Attribution (CC BY) license (http://creativecommons.org/licenses/by/4.0/). 